\title{
Sociocultural Intelligence And Prison Systems. The Fight Against Organised Crime Continues Beyond The Dismantling of Organisations
}

\author{
Daniel Sansó-Rubert Pascual
}

\begin{abstract}
Traditionally the fight against organised crime, as well as keeping any type of offensive measure outside of the prison environment, has been characterised by the absence of a minimum reflection about the strategies used, accumulating a number of significant strategic errors in the confrontation against the organised crime phenomenon. To the extent that, in recent decades, organised crime has taken the initiative. Having identified this reality and from a criminological perspective and that of the application of criminal intelligence capabilities, the prison system is configured as a fruitful field of research, useful to obtain sociocultural inputs (sociocultural criminal intelligence) which provide not only a better understanding of the organised criminal phenomenon, but also their leaders. This knowledge is based on criminological theories and allows for the development of focused deterrence and selective action strategies, not only against organisations as a whole or their activities and markets but also against their leaders, seeking thereby, the ultimate neutralisation of the phenomenon.
\end{abstract}

Keywords: organised crime, criminal intelligence, sociocultural intelligence, prison systems, criminal subculture

\section{INTRODUCTION}

Traditionally, the fight against organised crime has been characterised by the supremacy of action in detriment of well thought out strategies (Moreno, 2009; Sansó-Rubert, 2011; Gilmour and France, 2013), accumulating a plurality of significant strategic errors in the confrontation against the organised crime phenomenon (Felbab-Brown, 2013; Boer, 2013). To the extent that, in recent decades, organised crime has taken the initiative. Wrongly, it has been assumed that once the members of criminal organisations were arrested and placed at the disposal of the justice system, their organisations were dismantled and their members were put behind prison walls (García, 2004; Albanese, 2011; Sansó-Rubert, 2014). Similarly, using strategic and intelligence terms in the response to organised crime was the subject of criticism, arguing against the squandering of expensive and limited means to address the problem of the states' own internal security (Sansó-Rubert, 2010).

In trying to analyse criminal organisations as a whole, there is a wide variety of types that could be configured as a continuum. In the extremes one finds from small associations with slightly weak and unstable links to established structures, to consolidated structures that are notoriously well rooted and dangerous. The scene forms a ragtag group of organisations whose structure, discipline, internal rules, division of roles, idiosyncrasy, illegal activities and therefore, hazards, represent a plurality of combinations (De la Corte and Giménez-Salinas, 2010) that are generally ignored and, to date, little studied. 
The characterisation of organised crime as a phenomenon that faces a constant evolutionary process in order to adapt to the environment in which it intends to carry out its illegal activities so as to avoid a loss of competitiveness and efectiveness (Sansó-Rubert, 2008), has led to the configuration of an international scenario that is favourable to its interests, displaying a cross-cutting nature and a great capacity for criminal diversification. The succesful use of every opportunity to thrive and grow rich, coupled with a growing commitment to transnationalization, has hindered the fight against organised crime, with limited success achieved in global terms, differentiating in geographical terms the successes that have been achieved in specific areas (European Union, United States...), against the failure or the achievement of pyrrhic victories in areas such as Africa or some parts of Latin America like in the Central American Northern Triangle (Honduras, Guatemala and El Salvador) (Koonings and Krujit, 2004; Bybee, 2012).

Criminal top brass, composed by professional criminals that are characterised by having extensive criminal careers, have included in their activities and initiatives an extensive knowledge of strategy, deterrence and geopolitics that has brought them considerable success. "Criminal professionals" are identified as those who have made crime their modus vivendi, taking their arrests and the serving of sentences as another episode in their professional lives. From the standpoint of the criminal subculture this not only gives them prestige and also provides them with credibility in their profession and trust amongst their peers but also the ability to exercise leadership in the development of agreements and business opportunities (Requena, 2013; Pulido and Sansó-Rubert, 2014).

Having identified this reality and from a criminological perspective and that of the application of the criminal intelligence capabilities, the prison environment is configured as a rich environment from which to obtain inputs of a sociocultural nature (sociocultural criminal intelligence), which provide not only a better understanding of the organised criminal phenomenon but also provides a better understanding about its leaders. This is a knowledge based on criminological theories that allows for the development of focused deterrence and selective action strategies (Felbab-Brown, 2013), not only against organisations as a whole or against their activities and markets, but also its leaders. Seeking thereby, the definitive neutralisation of the phenomenon.

In short, the aim is to make good use of the enormous amount of valuable information on organised crime that currently gets diluted and dissapears into the Penal Administration structures because of a lack of infrastructure, capabilities and means (and political decisionmaking). This is information that, conveniently transformed into criminal intelligence, could help significantly in the fight against organised crime.

\section{CRIMINOLOGY AT THE SERVICE OF SOCIOCULTURAL CRIMINAL INTELLIGENCE: INTELLIGENCE ANALYSIS OF CRIMINAL SUBCULTURES, CRIMINAL CAREERS AND CRIMINAL ELITES}

Criminology as a discipline should not remain indifferent to studies on intelligence and security. This empirical and interdisciplinary science can provide extremely valuable elements for the analysis of factors and sociocultural variables of criminal subcultures. It provides criminal intelligence with the necessary scientific knowledge for the analysis destined for consumers, be they political decision-makers or heads of agencies responsible for the prosecution of crime; making sure that they have sufficient evidence for the adoption of appropiate responses. It consequently reduces the risks that are inherent in any action or 
decision when it comes to implementing efficient strategies. At the same time, it allows us to contrast the objective efficiency of the actions taken in this respect. It also provides knowledge about what has happened with the scenario subject to analysis, what is happening and why, and what is more likely to happen in the future (Sansó-Rubert, 2010 and 2012).

But what is sociocultural intelligence? And how is it approached from the perspective of organised crime? Sociocultural intelligence is the ability to recognize shared beliefs, values, attitudes and behaviours of a group of people and, most importantly, to effectively apply that knowledge to a specific goal or set of goals. It is the result of the integration of numerous human dimensions which aim to improve understanding, interpretation and evaluation of acquired knowledge applicable to the specific culture under observation as a result of the integration of information both from open and closed sources (Navarro, 2012).

In the case in question (criminal subcultures), criminal behaviour is an eminently social product that is learned from the relationship with the primary groups and peers and friends. Criminal actions need to be learned in the same way as those that are law-abiding. Criminals try to get rich like people who have conventional jobs, but they choose an illegal way to do it (Giddens, 2000).

The criminal phenomenon, like any other social phenomenon, is closely related to the realities that surround it. Crime does not take place in the "abstract", but it occurs under certain spacetime conditions. These circumstances strongly influence the way that crime occurs, the way in which it manifests itself, its quantity, intensity and all its connotations and pecularities (Durkheim, 1997: 93 and 97).

Over the years it is possible to identify how organised crime as a phenomenon, regardless of geographical space or scope (national or transnational), types of criminal activities or any other individual characteristic of a particular group or organization, has been building and consolidating a symbolic ideological and cultural perception which has contributed to shaping the justification and moral and ethical artifices of its self-legitimacy.

In addition to increasing their specialisation, flexibility and commitment to internal cohesion of their criminal networks, coupled with the use of a particular language (jargon), criminal groups have built and share a specific set of values, norms and behavioural patterns. It is a formalised and systematised ideological representation of deviation (Córdova, 2007).

Such a sociocultural deviation is the result of a number of motivations such as the need to climb the social structure and the resentment and desire for social revenge that leads to violence and destructiveness. But these also involve the rationality of being able to achieve economic gains and access to the exercise of power. In many parts of the world, immersion in organised crime is the only way for large swathes of people that come from disadvantaged social strata mired in poverty and marginalization, to earn a salary and aspire to a better life through crime. It is the only vehicle towards accesible social mobility. Criminals, such as El Chapo Guzmán in Mexico, have become important sociocultural references to emulate, increasing the attractiveness of criminal subcultures (Buscaglia, 2013; Bailey, 2014).

In turn, as organised crime becomes more globalised, the elements, features and components of its most significant, transcendent and meaningful cultural identity are highlighted, remaining with or getting diluted into the local culture. As they settle and take root, criminal 
groups manage to keep their ethnic, cultural and, where posible, territorial links (Córdova, 2007). This is where much of its strength and appeal resides.

In this sociocultural context, it is not only the criminal organisation but also the individual (professional criminal), that becomes relevant. Criminological theories allow us to understand, from a strategic level, the criminal potential of relevant individuals within criminal organisations - especially when they are at the top of the hierarchy - in order to implement deterrence strategies or selective actions that can lead to the neutralisation of the organisation.

Although the country-risk analysis is one of the methodologies used by intelligence at a strategic level, it is not very often that the criminological theoretical justification has been used to explain potential patterns of behaviour.

The theoretical transposition in the identification of potential indicators of professional crime is something new. In this regard, the combination of analytical methodologies in strategic intelligence along with the application of these theories helps to understand and establish patterns of behaviour.

The identification of subjects catalogued in the risk and threat spectrum through the measurement of the willingness to commit criminal acts is usually established based on the membership of the subject to a criminal community, obviating behavioral patterns caused by the environment or by structural imbalances of a social nature (cultural intelligence).

The proposal to combine strategic criminal intelligence with the criminological identifying criteria of a sociocultural nature (criminal subculture), is based on the theoretical justification for the recourse to focused deterrence and selective action strategies. Knowledge of the behavioural patterns will be necessary to identify warning indicators on specific criminal behaviour. And the prison environment stands out as a rich space for the gathering of information and knowledge. The development of this has yet to be exploited conveniently.

Consider, for instance, the application of the criminological theory of rational choice to the leadership of criminal organisations (Becker, 1968; Felson and Clarke, 2009; Roemer, 2012). It is an appropiate explanatory framework under which to circumscribe the paths of action of organised criminal groups in virtue of the decisions adopted by their leaders.

Logically, this approach leads us to assume that organised crime is a phenomenon where rationality prevails. An issue that, strictly speaking, would not be entirely true. However, it can be assumed according to the authoritative information available, that usually the leaders of organised criminal organisations are self-interested rational actors (Shelley, Picarelli et. Al., 2005). Organisations can be regarded as rational actors, focusing exclusively for this analysis on the groups as a whole and in the decisions taken exclusively by their leaders. In this starting analytical context, the rationality of the remaining members is excluded as they are not decision makers within the organisation. It is assumed that decisions taken to interact with other groups, to participate in certain activities or, in general terms, decisions affecting the organisation as a whole, will be taken at the highest level of the leadership (Morselli, 2009).

Consequently, the variant of the mainstream rational choice theory "assumes that all individuals have the rational capacity, time and emotional detachment needed to choose the 
best course of action in a given situation" (Marsh and Stoker, 1995; Anderton and Carter, 2005; Williams, 2006): the maximisation of profit or obtaining an advantage in a given situation.

Finally, within the framework of relations established between criminal subcultures, it has become particularly relevant to establish links between criminal organisations and terrorists. This occurs when one of the organisations adopts a certain modus operandi similar to the other and makes it their own, reproducing it mimetically. This "borrowing" or "appropiation" (Shelley, Picarelli et. Al., 2005) simply highlights the recognition of the validity or the success of certain paths of action when undertaking certain activities. Thus, terrorist organisations emulate criminal organisations - especially when it comes to different ways to launder money and for logistics - to achieve their objectives, wether these are survival, funding or destabilization. Similarly, criminal organisations find it profitable to employ terrorist methods to achieve their ends. The basic argument is that both types of phenomenon when they manifest themselves as organisations, can establish links (of a varied nature and intensity), as long as these links favour the increase of their capabilities in a way that facilitates the achievement of their respective goals, when independently they would not be able to do so. Basically, it is a purely utilitarian vision that conveniently exploits factors of opportunity for the sake of a set of previously fixed objectives.

In short, criminological studies in general and those on organised crime in particular constitute a reservoir of knowledge of remarkable value for the development and enrichment of intelligence. It applies to both basic intellingence (characterized by its generality and relative permanence through time), current intelligence (to keep basic intelligence up-to-date with new data and respond quickly and accurately to a request for information about a current scenario) and to estimative intelligence, intended to determine - given a particular situation and the request of the consumer - the posible evolution of a situation and the action variables of the elements taking part in it from the data available. This is also true of their operational, tactical and strategic aspects.

Ultimately, its multidisciplinary nature gives its academic products added value, facilitating a global understanding of the threat in a context of polymorph security and in continous transformation.

\section{STRATEGIES OF FOCUSED DETERRENCE AND SELECTIVE ACTION AGAINST ELEMENTS OF ORGANIZED CRIME BASED ON SOCIOCULTURAL CRIMINAL INTELLIGENCE OBTAINED IN PRISON ENVIRONMENTS}

Currently, in the fight against organised crime, deterrence focused and selective action strategies gradually gain recognition as promising alternatives.

This is due to the possibilities they offer in succesfully combating organised crime. Theoretically, under ideal circumstances, the security apparatus that is responsible for the fight against organised crime should respond uniformly and in a standardised manner to all criminal organisations that participate in the same type of illicit economic activities. Basically, the object of this standardised response would ensure an equitable state intervention against organised crime as a whole. Therefore preventing, by intervening on all fronts, the targeting of a particular organisation over others (Felbab-Brown, 2013).

The logic of this action finds its theoretical support in the so called criminological theory of "broken windows" (Kelling and Wilson, 1982). This approach holds that the fight against crime requires addressing all public order altercations, even minor ones, in order to communicate to 
society and potential offenders that a given space is subject to potential supervision and the State security apparatus has the ability and the willingness to enforce the law.

Faced with these theoretical postulates, reality manifests itself as perverse, given that we must asume that the means and resources available to respond to the manifestations of organised crime are limited. In this respect, to overcome the problems of limitation and dispersion of resources, deterrence focused and selective action strategies become relevant. They allow for the selective focusing of a target (to neutralise a criminal group or a chronic offender), in a limited geographical area (hotspots) of a variable dimension (a neighbourhood, a city, a province or throughout the whole national territory) with a double objective: the primary objective being the dismantling of the organisation or the neutralisation of the criminal subject, and the secondary objective being to send a message of deterrence to other organisations and their members to desist from their criminal activities or face becoming a target themselves (Kennedy, Tompkins and Garmise, 1998; Kennedy, 2011; Braga, 2012; Braga and Weisburd, 2012).

The underlying logic of these deterrence focused and selective action strategies, in addition to focusing the efforts of limited resources to achieve higher levels of success in neutralising organisations and individuals against the inneficient dispersion of resources, lies ultimately in trying to reduce the most harmful behaviours of criminal groups such as the use of violence, or to promote certain types of desirable behaviour by these groups, such as preventing their links to terrorists organisations (Felbab-Brown, 2013). Basically, getting criminal organisations to adopt autolimitation strategies by themselves, betting on them adopting low profiles and in general trying to avoid, as far as possible, becoming the next target of the selective action strategies used by the State.

The succesful implementation of these strategies that has been achieved in some countries, has led some authors to propose their internationalisation. The idea, originally proposed by Mark Kleiman in his work "Surgical strikes in the drug wars" (2011), urges that countries with a strong repressive capacity should address the dismantling of the most dangerous transnational criminal networks in order to help reduce the criminal activity and violence in other countries, where the ability and resources to deal with transnational organised crime are scarce or nonexistent. (Kleiman, 2001).

Logically, the criterion chosen to support the deterrence focused and selective action strategies (dangerousness, damage, institutional infiltration capacities, state destabilization capabilities, abusive use of violence, links to terrorist organisations...), should be the object of evaluation according to the local circumstances of each country on the basis of a comparative analysis of costs, benefits and gains. To do this, criminal intelligence provides informed "knowledge" that also allows authorities to anticípate and neutralise or deter threats, risks and conflicts linked to organised crime.

At this point it should be emphasized that criminal intelligence and its sociocultural off-shoot are merely types (typologies) useful to obtain, evaluate and interpret information and disseminate the necessary intelligence to protect and promote national interests of any nature (political, comercial, business) against organised crime, so as to prevent, detect, and enable the neutralisation of those criminal activities, groups or individuals who by their very nature, magnitude, foreseeable consequences, dangerousness, put at risk or violate the constitutional order, fundamental rights and freedoms (Sansó-Rubert, 2011). 
Similarly, its usefulness resides in its use as an analytical tool to measure the success of public policies and decisions taken in the confrontation against organised crime. It allows for the allocation of intelligence capabilities for conducting analysis on the public management and institutional strengthening of the state, in order to get a hindsight glimpse about how certain decisions in the management of public affairs (resources, goods and services) enable or facilitate operations and organisations operating outside the law, so that they can identify the implications of decisions and adopt preventive measures to avoid the inadvertent strengthening of organised crime.

Assuming that deterrence focused and selective action strategies and criminal intelligence itself, especially its cultural nuance, are the preferred tools for optimising results in the fight against organised crime, the crux of the question is how to exploit the aspect related to the maximization of the information that can be obtained from various criminal subcultures? Everybody knows the inherent difficulty that characterises any effort to approach organised crime as a phenomenon of study. Therefore, to solve this analytical limitation, the use of the prison system as a source of information allows us to bypass this initial obstacle. Not surprisingly, a good part of members of criminal organisations are temporarily and partially constrained within the confines of the prison system, making them a good object of study.

I must emphasize the temporality and partiality of this subject, given that from a comparative criminological perspective we should also analyze existing international prison systems as a factor that has contributed to the emergence, development and expansion of organised crime. Organised crime operates inside and outside prisons and, in the same way that it dominates certain physical spaces in detriment of state authority (neighbourhoods, cities, parts of the national territory...), for several years prison systems have been undergoing a process of decay, corruption and mismanagement which has allowed criminal organisations to take over their control, sometimes in collusion with political power; what Roy Godson has called the political-criminal link (Godson, 2004).

Consequently, the adaptability of the criminal organisations that continue to operate within our prisons demands at the very least the same adaptability of the instruments available to ensure security; deploying resources and capabilities devoted to criminal intelligence in order to provide agencies with responses that are smart, preventive and proactive so as to tackle the increasing expansion of organised criminal activity.

In short, getting the most out of the vast and valuable information (sociocultural) about organised crime that, currently, is being diluted and dissappearing into the bowels of the Penal Administration system for lack of infrastructure, capabilities and resources (and political decisions). This constitutes information that properly transformed into criminal intelligence, could help significantly in the fight against organised crime.

\section{EXPLOITATION OF SOCIOCULTURAL CRIMINAL INTELLIGENCE IN THE PRISON CONTEXT}

The efficient exploitation of criminal intelligence in a prison context requires addressing challenges inherent to organised criminal phenomenology on the one hand, and the particularities of the prison environment on the other.

Thus, with regard to the etiology of organised crime, the main challenge that must be faced is the commitment of the organisations and their members towards the supression of evidence and also forensic prophylaxis. Both consist of a large number of actions of a diverse nature, 
preventive and reactive, destined to nullify the efectiveness of infiltration and counterintelligence. In this sense, the criminal organisations carry out activities of self protection, destruction of evidence and informative intoxication (disinformation) and even the implementation of lures (honeypots), to test and measure the response of security government agencies and intelligence services. Through such schemes, they can detect the degree of exposure, surveillance and monitoring that their members are under (Sansó-Rubert, 2010).

At the same time they develop strategies to obtain information on the political, economic and security fields, enabling them, if possible, to conveniently exploit them through the use of corruption or the recourse to violence, permeating public and private institutions and trying to establish contacts which might contribute to the safeguarding of the organisation and its members.

Criminologically speaking, other characteristic elements of the masking of criminal activity include the structure adopted by the organisation itself. Hence the tendency to copy operational and management procedures from the business environment, promoting illegal control of the legal economic sector both in the public and private spheres (Fijnaut, 2000), in order to provide legal cover for their illegal activities. The threat that comes from organised criminal groups that adopt a network structure should be particularly emphasized (Arquilla and Ronfeldt, 2003) as it gives them operational advantages as well as additional protection against security agencies. Thus, by partitioning the group (and information) in cells with varying degrees of autonomy, only the highest echelons of the organisation have the knowledge and the ability to make decisions both at the organisational and functional level, hindering any infiltration attempts.

Among the full range of ways to obtain information within the prison system, the interception of communications both verbal and written should be highlighted. To maximise the dynamism of their activities and ensure their continued operation, organisations need to maintain open and fluid communication channels that include those parts of the structure that find themselves within the prison system. In this regard, rather than disrupting the communications, the objective should be the access to the content of those communications.

At this point there is a "clash of brains" between the mechanisms that criminals develop to protect their communications and the creativity of the members of the security apparatus in intercepting them. It is a struggle that also ensues when neutralising the activity of criminal organisations, which constantly renew their methodologies and modus operandi with which they can surprise their victims, competitors and persecutors alike. At this point, the use of criminal intelligence capabilities seeks to reclaim the lost initiative against organised crime, anticipating their strategies and acting accordingly before they come to fruition.

Criminal intelligence work allows for the detection and deciphering of the mechanisms used to hide and encrypt communications (new alphabets, alphanumeric codes, "rebound communications" (techniques whereby a prisoner writes a letter to somebody outside of prison unrelated to the organisation and this person makes sure that it gets to the right place)). Usually, it is a relative or a friend, or a simple courier for the organisation (Knox, 2005). Similarly, inmates that are not members of the organisation (motivated by economic gain or coerced) are used to act as human mail carriers taking advantage of home permits or parole. The ways to evade the control exercised over communications are as varied as the imagination will allow. 
Here, it is important to emphasize the limitations that exist in relation to the right to secrecy of communications depending on wether we find ourselves in a prison system under democratic rules or not; especially in the inmate's personal encounters with their spouse and in their interviews with their legal teams. Nowadays, despite being aware that this is how the exchange of sensitive information for the operation of criminal organisations occurs (information, instructions, orders), it is not possible to circumvent the law and violate fundamental rights to conduct wiretapping without the due preliminary judicial overview. A different matter would be the interception of communications via mobile phones or through any media platforms (satellite phones, internet....prohibited in any prison) and the exploitation of their contents.

Other sources of criminal intelligence that are useful are the observation and analysis of relationship flows throughout the prison system (contacts and links established or broken between organisations and certain people within the criminal structures). It is relevant to take into consideration the disagreements between organisations. Disputes and disagreements move from the outside to the inside of prisons and viceversa, triggering violent clashes and killings which directly affect the functionality and the stability of the penal institution. Also, clashes in prisons may occur for control of certain illegal activities (drug trafficking, smuggling of objects susceptible to revaluation: alcohol, drugs, medicines or tobacco...) between rival organisations present in the prison.

Despite the importance expressed in relation to other sources of information, human intelligence (HUMINT) rises above the others in the fight against organised crime. And, in prisons this increases its value given the difficulties in its exploitation inside of prisons. Although there are cases of infiltration of undercover agents in prison (Cabezas, 2004), they are few and far between given the danger that the agent exposes himself to, and the difficulties in trying to maintain his anonimity while he is incarcerated- it is far more common to try to recruit informants or people who repent their crimes in prison. They dont raise suspicions amongst the organisation and through them, important, relevant information can be gleaned from the organisation, especially its leaders. Collaborators are also employed in equal measure to carry out deception and informative intoxication (disinformation) techniques that lead to the neutralisation of illegal activities and the collapse of the organisations.

The objectives of covert operations range from hampering the ordinary activities of the organisation causing instability, the mere gathering of information, the creation of dysfunctional relationships that break down the capabilities of the criminal group, actions to destroy trust between their leaders by providing false information and creating suspicion and internal acrimony (disinformation), even direct attacks (physical elimination, destruction of infrastructures and means) to the organisation with the aim of interrupting its activities, degrade its capabilities or even destroy it completely.

The task of attracting collaborators is not easy, due to the tight control which organisations exert over their imprisoned members to prevent leaks and infiltrations. Many organisations even destine money for the maintenance of the family of their jailed cadres, giving them an allowance (equivalent to a wage) while their relative remains deprived of freedom. Such initiatives, coupled with the imposition of a sort of corporate security strategy (omertá, or law of silence) makes this task difficult, but not impossible. In the field of organised crime, information, as loyalties, are bought and sold. One only has to come up with the right price or 
the personal motivation for it (economic, revenge, regret...) It is not personal, only business (Ferrante, 2012).

In conclusion, the exploitation of criminal intelligence allows, on the one hand, not only a better understanding of the criminal phenomenon in all its spectrum but, in turn, provides "informed" knowledge indispensable for the deployment of all those resources (formal social control: criminal policy, security and defense policy, penitentiary, legislative measures, policing...) at the operational, tactical and strategic levels, aimed at neutralising the criminal risk.

Although criminal intelligence provides a broad range of opportunities for action against organised crime, we should not forget about the internal challenges: reflected in the (sometimes) lack of technical and human means, this is very important when taking into consideration the fact that something like this should not be improvised. One thing that stands out negatively is the serious lack of translators in detention centers, precisely at the stage in criminal history where the transnationalisation of the organised criminal phenomenon is on the rise. The lack of idiomatic and dialectal knowledge is conveniently used by members of criminal organisations to protect the secrecy of their communications.

\section{SUCCESS OR FAILURE. A QUESTION FOR THE FUTURE}

Given the magnitude of the threat posed by organised crime, the development of strategies and tools to neutralize organised criminal activity, especially in its transnational dimension, and promote cooperation and coordination at the national and international levels, should constitute priorities for governments in the 21st Century. Therefore, capacity building and the exploitation of criminal intelligence, both within and outside prison systems, confers distinct advantages allowing us to minimise the impact of crime especially when the cost of opportunity when it comes to making a decision (and not another) could be qualitatively more burdensome or generate irreparable damage.

Given the difficulties of the exploitation of criminal intelligence in prisons, as well as the opportunities it brings us, the effort is worth the sacrifices. Thus, a good product of criminal intelligence not only describes what the current situation regarding the phenomenon is, but provides explanations on the existence of the phenomenon and establishes possible developments or trends, defining possible and probable scenarios. It also defines the viable alternatives to redirect the situation in a way that can lead to its eradication and control, and establishes the potential and social costs resulting from the application of such measures.

In the same way, it allows us to know and analyse the geographical distribution of criminal activity, the territorial concentration of criminal organisations (criminal density), the emergence of new niches of illicit markets, the introduction of new technologies and modus operandi, new products and services, the identification of strategies implemented by criminal structures, familiarization with criminal subcultures - especially its prison variants -, the relevant sociodemographic characteristics of members of criminal organisations (nationality, region of origin, ethnicity, family, profession, status as former policemen or former combatants, type of illegal activity that they specialise in...) as well as detecting the rise and fall of criminal organisations. There is a constant dynamic in the criminal world leading to some groups declining and others emerging: the difficult thing for them is to persevere through time. 
To put it simply, criminal intelligence products are the result of systematic processes of production and dissemination of useful knowledge on crime in its various dimensions and within the social contexts in which they occurs. Therefore, criminal intelligence must aspire to something more than just to produce descriptive reports. The analysis at the strategic level must pass through foresight, focusing its scrutiny of the criminal reality into the future; predicting future scenarios, adscribing probability and desirability to them, so as to be able to design appropiate plans under predetermined objectives in order to acquire a deep understanding of the etiology of organised crime and its phenomenology.

Similarly, criminal intelligence stands out as the optimal tool for developing security strategies that allow us to reorganise the instruments and procedures available to governments to tackle complex crime, and to help redefine the objectives in the fight against organised crime: establish the policy and plans to implement and achieve targets; identify and understand the elements and factors favoring the emergence and expansion of organised crime, paying attention to the appearance of signs and the evolution of risk indicators in order to achieve early detection prior to its materialisation, as well as to discover and identify anything that might mean a chance of success for organised crime.

\section{BIBLIOGRAPHY}

ALBANESE, Jay S. (2011). Transnational Crime and the 21st Century: Criminal Enterprise, Corruption and Opportunity. New York: Oxford University Press.

ANDERTON, Charles H. and CARTER, John R. (2005). "On Rational Choice Theory and the Study of Terrorism". Defense and Peace Economics, n.16; (4), pgs. 442-458.

ARQUILLA, John and RONFELDT, David (2003). Redes y guerra en red. El futuro del terrorismo, el crimen organizado y el activismo político. Madrid: Ed. Alianza.

BAILEY, John (2014). Crimen e impunidad. Las trampas de la seguridad en México. Barcelona: Debate.

BECKER, Gary (1968). “Crime and Punishment: An Economic Approach”. The Journal of Political Economy, Vol. 76, n.2, pgs. 169-217.

BOER, Mónica den (2013). "Go with the flow and undo the Knots: Intelligence and interconnectivity in transnational organized crime policing". In: Allum, F. and Gilmour, S. (Eds). Routledge Handbook of Transnational Organized Crime. London and New York: Routledge.

BRAGA, Anthony (2001). "The effects of hot spots policing on crime". American Academy of Political \& Social Science, n.578, pgs. 104-125.

BRAGA, Anthony (2012). “Getting deterrence right?". Criminology and Public Policy, n.11 (2), pgs. 201-210.

BRAGA, Anthony and WEISBURD, David (2012). "The effects of focused deterrence strategies on crime: A systematic review and meta-analysis of the empirical evidence". Journal of Research in Crime and Delinquency, n.49 (3), pgs. 323-358.

BUSCAGLIA, Edgardo (2013). Vacíos de poder en México. Cómo combatir la delincuencia organizada. Barcelona: Debate.

BYBEE, Ashley, N. (2012). "The Twenty-First Century Expansion of the Transnational Drug Trade in Africa”. Journal of International Affairs, Vol. 66, n.1.

CABEZAS, Jorge (2004). Infiltrados. De ETA a Al Qaeda. Barcelona: Planeta Actual.

CÓRDOVA, Nery (2007). "La subcultura del "Narco" en Sinaloa: la fuerza de la transgresión". Cultura y representaciones sociales, Vol.2, n.3. México D.F.: Universidad Nacional Autónoma de México (UNAM), pgs. 106129.

DE LA CORTE, Luis and GIMÉNEZ-SALINAS, Andrea (2010). Crimen.org. Evolución y claves de la delincuencia organizada, Barcelona, Ariel. 
Pascual, D. S. R. (2017). Sociocultural Intelligence And Prison Systems. The Fight Against Organised Crime Continues Beyond The Dismantling Of Organisations. Advances in Social Sciences Research Journal, 4(3) 13-25.

DURKHEIM, Emile (1997 - reprinted). Las reglas del método sociológico. México D.F.: Editorial Fondo de Cultura Económica.

FIJNAUT, Cyrile (2000). "Transnational crime and the role of the United Nations in its containment through international cooperation: a challenge for the 21st century". European Journal of Crime, Criminal Law and Criminal Justice, n.8, pgs. 119.

FELBAB-BROWN, Vanda (2013). Modernizando la aplicación de la ley. Informe 2. Disuasión focalizada, acción selectiva, tráfico de drogas y delincuencia organizada: conceptos y prácticas. Consorcio Internacional sobre Políticas de Drogas. Consulted in https://dl.dropboxusercontent.com/u/64663568/library/MDLE-report-2 Focuseddeterrence SPANISH.pdf

FELSON, Marcus and CLARKE, Ronald (2009). “La ocasión hace al ladrón. Teoría práctica para la prevención del delito”. Serie Claves del Gobierno Local, n.6. Fundación Democracia y Gobierno Local, pgs. 193-234.

FERRANTE, Louis (2012). Aprenda de la Mafia. Para alcanzar el éxito en su empresa (legal). Barcelona: Conecta.

GARCÍA, Sergio (2004). “Crimen y prisión en el nuevo milenio”. Boletín Mexicano de Derecho Comparado, n. 110, pgs. 547-595.

GIDDENS, Anthony (2000). Un mundo desbocado. Madrid: Taurus.

GILMOUR, Stan and FRANCE, Robert (2013). "Local policing and transnational organized crime”. In: Allum, F. and Gilmour, S. (Eds). Rotledge Handbook of Transnational Organized Crime. London and New York: Routledge.

GODSON, Roy (Ed). (2004). Menace to Society: Political-criminal Collaboration Around the World. Transaction Publishers: New Brunswick (USA) and LONDON (UK).

KELLING, George and WILSON, James Q. (1982). "Broken Windows”, The Atlantic, 249 (93), pgs. 29-38.

KENNEDY, David (2011). Don't shoot: One man, a street fellowship, and the end of violence in inner-city America. New York: Bloomsberry.

KENNEDY, David; TOMPKINS, Daniel and GARMISE, Gayle (1998). "Pulling levers: Getting deterrence right". National Institutte of Justice Journal, n.236, pgs. 2-8.

KLEIMAN, Mark (2011). "Surgical strikes in the drugs wars”. Foreign Affairs, n.90 (5), (september/october), pgs. 89-101.

KNOX, George W. (2005). "The Problem of Gangs and Security Threat Groups (STG's) in American Prisons Today: Recent Research Findings from the 2004 Prison Gang Survey". National Gang Crime Research Center.

KOONINGS, Kees and KRUJIT, Dirk (Eds.) (2004). Armed actors, organized violence and state failure in Latin America: a survey of issues and arguments. Zed Books: London and New York.

MARSH, David and STOKER, Gerry (1995). Theory and Methods in Political Science. London: Macmillan.

MORENO, Fernando (2009). "Análisis crítico de los informes de evaluación de la amenaza del crimen organizado en la Uni'n Europea (Organized Crime Threat Assesment, OCTA)”. Documento de Trabajo (26/2009). Real Instituto Elcano. Available at: http//:www.elcano.org

MORSELLI, Carlo (2009). Inside Criminal Networks. New York: Springer.

NAVARRO BONILLA, Diego (2012). "Variantes del análisis como especialización profesional: retos y oportunidades de la inteligencia sociocultural”. In: Fernández Rodríguez, J.J.; Sansó-Rubert Pascual, D.; Monsalve, R.; Pulido Gragera, J. (Eds.). Cuestiones de Inteligencia en la sociedad contemporánea. Madrid: Ministerio de Defensa - Centro Nacional de Inteligencia, pgs. 127-142.

PULIDO, Julia and SANSÓ-RUBERT, Daniel (2014). "A Phenomenological Analysis of Terrorism and Organized Crime from a Comparative Criminological Perspective”. Journal of Law and Criminal Justice. December 2014, Vol. 2, n. 2, Published by American Research Institute for Policy Development, pgs. 113-131.

REQUENA, Laura (2013). Principios generales de Criminología del desarrollo y las carreras criminales. Barcelona: Editor J.M. Bosch.

ROEMER, Andrés (2012). Economía del crimen. México: Noriega Editores.

SANSÓ-RUBERT PASCUAL, Daniel (2008). "Criminalidad organizada transnacional y seguridad internacional”. In: Fernández Rodríguez, J.J., Jordán, J., and Sansó-Rubert Pascual, D. (Eds.); Seguridad y Defensa hoy. Construyendo el futuro, Madrid: Plaza y Valdés Editores, pgs. 207-240. 
SANSÓ-RUBERT PASCUAL, Daniel (2010). "Inteligencia criminal. Retos y oportunidades para la acción frente a la delicuencia organizada”. In: Velasco, F.; Navarro, D. and Arcos, R. (Eds.). La inteligencia como disciplina científica. Madrid: Plaza y Valdés - Ministerio de Defensa, pgs. 191-204.

SANSÓ-RUBERT PASCUAL, Daniel (2011). "Inteligencia criminal: una elección estratégica en clave de seguridad frente a la iniciativa de la delincuencia organizada”. In: Rivera Vélez (Ed.). Inteligencia estratégica y prospectiva. Ecuador (Quito) Flacso-Senain-AECID, pgs. 215-238.

SANSÓ-RUBERT PASCUAL, Daniel (2012). "Estrategias de Seguridad, criminalidad organizada e inteligencia criminal: una apuesta de futuro”. In: Fernández Rodríguez, J.J.; Sansó-Rubert Pascual, D.; Monsalve, R.; Pulido Gragera, J. (Eds.). Cuestiones de Inteligencia en la sociedad contemporánea. Madrid: Ministerio de Defensa Centro Nacional de Inteligencia, pgs. 204-219.

SANSÓ-RUBERT PASCUAL, Daniel (2014). "Inteligencia criminal y sistemas penitenciarios: algunas reflexiones”. Revista Latinoamericana de Estudios de Seguridad, URVIO, n. 15, pgs. 98-111.

SHELLEY, Louise and PICARELLI, John. (2005). "Methods and Motives: Exploring Links between Transnational Prganized Crime and International Terrorism”. Report for the US Department of Justice, funded by Grant 2003-IJCX-1019. September. Available at: http//:www.ncjrs.gov/pdffiles1/nij/grants/211207.pdf

WILLIAMS, Phill (2006). "Strategy for a New World: Combating Terrorism and Transnational Organized Crime”. In: John Bailey, Eliot Cohen and Colin S. Grey. (Eds.). Strategy in the contemporary World: An Introduction to Strategic Studies. Oxford: Oxford University Press. 